Texas Southern University

Digital Scholarship @ Texas Southern University

Faculty Publications

3-1-2021

\title{
Discovery of Clioquinol and analogues as novel inhibitors of Severe Acute Respiratory Syndrome Coronavirus 2 infection, ACE2 and ACE2 - Spike protein interaction in vitro
}

\author{
Omonike A. Olaleye \\ Texas Southern University \\ Manvir Kaur \\ Texas Southern University \\ Collins Onyenaka \\ Texas Southern University \\ Tolulope Adebusuyi \\ Texas Southern University
}

Follow this and additional works at: https://digitalscholarship.tsu.edu/facpubs

\section{Recommended Citation}

Olaleye, Omonike A.; Kaur, Manvir; Onyenaka, Collins; and Adebusuyi, Tolulope, "Discovery of Clioquinol and analogues as novel inhibitors of Severe Acute Respiratory Syndrome Coronavirus 2 infection, ACE2 and ACE2 - Spike protein interaction in vitro" (2021). Faculty Publications. 30.

https://digitalscholarship.tsu.edu/facpubs/30

This Article is brought to you for free and open access by Digital Scholarship @ Texas Southern University. It has been accepted for inclusion in Faculty Publications by an authorized administrator of Digital Scholarship @ Texas Southern University. For more information, please contact haiying.li@tsu.edu. 


\title{
Discovery of Clioquinol and analogues as novel inhibitors of Severe Acute Respiratory Syndrome Coronavirus 2 infection, ACE2 and ACE2 - Spike protein interaction in vitro
}

\author{
Omonike A. Olaleye ", Manvir Kaur, Collins Onyenaka, Tolulope Adebusuyi \\ Department of Pharmaceutical and Environmental Health Sciences, College of Pharmacy and Health Sciences, Texas Southern University, 3100 Cleburne St, Houston, TX \\ 77004, USA
}

\section{A R T I C L E I N F O}

\section{Keywords:}

Severe acute respiratory syndrome coronavirus 2

Angiotensin-converting enzyme 2

Receptor binding domain

Coronavirus disease 2019

Clioquinol

\begin{abstract}
A B S T R A C T
Severe Acute Respiratory Syndrome Coronavirus 2 (SARS-CoV-2), the etiological agent for coronavirus disease 2019 (COVID-19), has resulted in an ongoing pandemic. Presently, there are no clinically approved drugs for COVID-19. Hence, there is an urgent need to accelerate the development of effective antivirals. Herein, we discovered Clioquinol (5-chloro-7-iodo-8-quinolinol (CLQ)), a Food and Drug Administration (FDA) approved drug, and two of its analogues (7-bromo-5-chloro-8-hydroxyquinoline (CLBQ14); and 5, 7-Dichloro-8-hydroxyquinoline (CLCQ)) as potent inhibitors of SARS-CoV-2 infection-induced cytopathic effect in vitro. In addition, all three compounds showed potent anti-exopeptidase activity against recombinant human angiotensin-converting enzyme 2 (rhACE2) and inhibited the binding of rhACE2 with SARS-CoV-2 Spike (RBD) protein. CLQ displayed the highest potency in the low micromolar range, with its antiviral activity showing a strong correlation with inhibition of rhACE2 and rhACE2-RBD interaction. Altogether, our findings provide a new mode of action and molecular target for CLQ and validates this pharmacophore as a promising lead series for the clinical development of potential therapeutics for COVID-19.
\end{abstract}

1. Introduction

Severe Acute Respiratory Syndrome Coronavirus 2 (SARS-CoV-2), a novel RNA betacoronavirus, is the causative agent for coronavirus disease 2019 (COVID-19), which has emerged as an ongoing pandemic (World Health Organization, 2020a). Worldwide, SARS-CoV-2 has spread rampantly to more than 192 countries/regions and has resulted in $105,097,000$ confirmed cases, 58,465,536 recovered, including 2,289, 979 deaths (Johns Hopkins Center for Systems Science and Engineering, Coronavirus resource center). Within the United States alone, there are more than $26,716,484$ cases and a total of 458,105 deaths as of February 5,2021 , according to the Johns Hopkins COVID-19 dashboard. About $80 \%$ of people infected with SARS-CoV-2 experience mild symptoms or are asymptomatic (World Health Organization, 2020b). A majority of symptomatic patients with moderate to severe symptoms have shown a broad range of clinical manifestation and/or significant complications, including severe pneumonia, multi-organ failure, acute cardiac injury, neurological damage, septic shock, acute respiratory distress syndrome (ARDS) (Zhu et al., 2020; Huang et al., 2020; Madjid et al., 2020; Mao et al., 2020). Recent reports revealed that individuals with pre-existing medical conditions have increased risk of COVID-19 related morbidity and mortality (Guan et al., 2020). Currently, there are no U.S. Food and Drug Administration (FDA) approved drugs for the treatment of COVID-19; but several studies are investigating the potential utility of repurposing clinically approved drugs as treatment options for COVID-19 (National Institute of Health (NIH), 2020; Sanders et al., 2020; Slomski, 2020; Horby et al., 2020; Verma et al., 2020). To date, only Remdesivir, an inhibitor of RNA-dependent RNA Polymerase, has been granted emergency use authorization (EUA) for the treatment of hospitalized patients with severe cases of COVID-19 (Food and Drug Administration (FDA), 2020).

Historically, Clioquinol (5-chloro-7-iodo-8-quinolinol (CLQ)) and its derivatives belonging to the 8-hydroxyquinoline structural class has shown potent broad-spectrum activity against clinically relevant pathogens (You et al., 2018; Bednarz-Prashad and John, 1983; Auld et al., 1974; Olaleye et al., 2011; Darby and Nathan, 2010; Tavares et al., 2018; Bohlmann et al., 2018). More recently, CLQ and its analogues have been extensively investigated as potential treatments for cancer and

\footnotetext{
* Corresponding author.

E-mail address: Omonike.olaleye@tsu.edu (O.A. Olaleye).
} 
neurodegenerative diseases (Schimmer et al., 2012; Ayton et al., 2015; Tavares et al., 2020; Cherny et al., 2012; Lannfelt et al., 2008; Ritchie et al., 2003; Adlard et al., 2008; Shi et al., 2020). Additional studies have also shown the involvement of CLQ in the efflux mechanisms of ATP binding cassette (ABC) transporters (Perez et al., 2019; McInerney et al., 2018) and the cellular autophagic pathway (Yu et al., 2009; Ding et al., 2005), a critical process in the host defense machinery against viral infections (Choi et al., 2018). Furthermore, using a high-throughput screen (HTS) and chemical genomics approach, Olaleye, O., et al. identified and characterized CLQ and certain analogues as potent inhibitors of methionine aminopeptidase (Olaleye et al., 2011), a universally conserved metalloprotease required for $\mathrm{N}$-terminal methionine excision (Lowther and Matthews, 2000; Giglione et al., 2003). As an established metal chelator and Zinc ionophore, CLQ modulates underlying molecular and physiologic machinery required for metal homeostasis (Yu et al., 2009; Ding et al., 2005, 2008; Haase et al., 2008; Lind et al., 2009; Andersson et al., 2009). Altogether, these pharmacologic properties of CLQ make it an attractive drug for potential targeting of angiotensin-converting enzyme 2 (ACE2).

ACE2 is a Zinc metalloprotease and essential cellular receptor for SARS-CoV-2 entry into host cells (Wrapp et al., 2020; Yan et al., 2020; Wang et al., 2020; Walls et al., 2020). Therefore, rapid identification of potent and selective ACE2 inhibitors have the prospects of accelerating the clinical development of preventative interventions and/or treatment options for COVID-19. ACE2 is mainly expressed in alveolar epithelial cells of the lungs, heart, kidney, and gastrointestinal tract (Hamming et al., 2004; Harmer et al., 2002). Although ACE2 is the cellular receptor for SARS-CoV-2 (Wrapp et al., 2020; Yan et al., 2020; Wang et al., 2020; Walls et al., 2020); ACE2 primarily functions as a carboxypeptidase that catalyzes the conversion of a single residue from angiotensin (Ang II), generating L-phenylalanine and Ang (1-7), a potent vasodilator, thus playing a critical role in controlling hypertension, renal disease, cardiac function and lung injury (Warner et al., 2003; Kuba et al., 2005). The crystalline structure of the ACE2 shows two domains; an N-terminal Zinc metallopeptidase domain (MPD) capable of binding the viral envelope-anchored Spike (S) glycoprotein of coronaviruses and a C terminal "collectrin-like" domain (Towler et al., 2004; Li et al., 2005; Li, 2015). The interaction of the MPD of ACE2 and S glycoprotein of SARS-CoV-2 is the initial and critical step in viral infection by receptor recognition and fusion of host and viral cellular membranes 2 (Wrapp et al., 2020; Yan et al., 2020; Wang et al., 2020; Walls et al., 2020). In addition, viral entry requires priming of $S$ protein by a host protease into S1 and S2 subunits, which are responsible for receptor attachment and membrane fusion, respectively (Song et al., 2018; Kam et al., 2009; Hoffmann et al., 2020; Belouzard et al., 2009). A receptor-binding domain (RBD) of the S1 subunit specifically recognizes ACE2 on human cells (Wrapp et al., 2020; Yan et al., 2020; Wang et al., 2020; Walls et al., 2020). Binding of the S1 subunit to ACE2 receptor triggers a conformational change in $\mathrm{S}$ glycoprotein from metastable pre-fusion state to stable post-fusion conformation, resulting in shedding of S1 and transition of the S2 subunit to expose a hydrophobic fusion peptide (Wang et al., 2020; Kirchdoerfer et al., 2016; Gui et al., 2017). The initial priming at S1/S2 boundary promotes subsequent cleavage at the S2 site by host proteases, which is critical for membrane fusion and viral infectivity (Belouzard et al., 2009; Millet and Whittaker, 2015; Madu et al., 2009). Therefore, targeting the interaction between the human ACE2 receptor and the RBD in the S protein of SARS-CoV-2 could serve as a promising approach for the development of effective entry inhibitors for potential prevention and/or treatment of COVID-19.

In this study, we evaluated the effect of CLQ and two of its analogues (7-bromo-5-chloro-8-hydroxyquinoline (CLBQ14); and 5, 7-dichloro-8hydroxyquinoline (CLCQ)) on SARS-CoV-2 infection-induced cytopathic effect (CPE) in vitro. In addition, we assessed the cytotoxicity of these compounds. Furthermore, we determined the impact of all three compounds on recombinant human ACE2 (rhACE2) interaction with the $\mathrm{RBD}$ on the Spike protein of SARS-CoV-2; and independently assessed their effects on the exopeptidase activity of rhACE2. Herein, we discovered for the first time that CLQ, CLBQ14, and CLCQ effectively inhibits the novel SARS-CoV-2 infection-induced CPE in vitro, inhibited rhACE2, and its interaction with the Spike protein and rhACE2 exopeptidase activity in the low micromolar range. Thus, rapid optimization and preclinical development of CLQ and its congeners could potentially accelerate their consideration for repurposing as potential antiviral agents against COVID19, first in non-human primate (NHP) models of SARSCoV-2 infection, and subsequently in clinical trials.

\section{Materials and methods}

\subsection{Materials}

\subsubsection{Cell growth conditions and medium}

African Green Monkey Kidney Vero E6 cells (ATCC\# CRL-1586, American Tissue Culture Type) were maintained using medium purchased from Gibco (modified eagle's medium (MEM) Gibco (\#11095); $10 \%$ fetal bovine serum (HI FBS) Gibco (\#14000); Penicillin/Streptomycin (PS) Gibco (\#15140); 10U/mL penicillin and $10 \mu \mathrm{g} / \mathrm{mL}$ streptomycin (only in assay media)). For the SARS-CoV-2 infection-induced cytopathic effect (CPE) assay, cells were grown in MEM/10\% HI FBS and harvested in MEM/1\% PS/supplemented with $2 \%$ HI FBS. Cells were batch inoculated with SARS-CoV-2 USA_WA1/2020 (M.O.I. 0.002), which resulted in $5-10 \%$ cell viability $72 \mathrm{~h}$ post-infection.

\subsubsection{Compounds and preparation of stock solutions}

The small molecule inhibitors, 5-chloro-7-iodo-8-quinolinol (Clioquinol, CLQ; C0187-Lot JJ01 SPGN), and 7-bromo-5-chloro-8-hydroxyquinoline (CLBQ14; B1190-P61JD-FD)); were purchased from TCI America. 5, 7-dichloro-8-hydroxyquinoline (CLCQ; D64600Lot\#STBH7389) and Zinc Chloride $\left(\mathrm{ZnCl}_{2} ; 208086-\right.$ Lot\#MKCL1763) were purchased from Sigma Aldrich. We prepared $10 \mathrm{mM}$ stock solutions of the inhibitors in Dimethyl sulfoxide (DMSO; D8418Lot\#SHBL5613) purchased from Sigma Aldrich. For the CPE assay, compound samples were serially diluted 2-fold in DMSO nine times and screened in duplicates. Assay Ready Plates (ARPs; Corning 3764BC) predrugged with test compounds $(90 \mathrm{~nL}$ sample in $100 \%$ DMSO per well dispensed using a Labcyte (ECHO 550) are prepared in the Biosafety Level-2 (BSL-2) laboratory by adding $5 \mu \mathrm{L}$ assay media to each well.

\subsubsection{Method for measuring the antiviral effect of CLQ CLBQ14, and CLCQ}

The SARS-CoV-2 infection-induced cytopathic effect (CPE) assay and cytotoxicity assays were generated and performed through a sub-contract to Southern Research Institute (SRI), Birmingham, Alabama from Texas Southern University, Houston, Texas. The CPE reduction assay was conducted at SRI to screen for antiviral agents in high throughput screening (HTS) format as previously described (Maddox et al., 2008; Severson et al., 2007). Briefly, Vero E6 cells selected for expression of the SARS-CoV-2 receptor (ACE2; angiotensin-converting enzyme 2) are used for the CPE assay. Cells were grown in MEM/10\% HI FBS supplemented and harvested in MEM/1\% PS/supplemented with $2 \%$ HI FBS. Cells were batch inoculated with SARS-CoV-2 (M.O.I. $\sim 0.002$ ), which resulted in $5 \%$ cell viability $72 \mathrm{~h}$ post infection. Compound samples were serially diluted 2-fold in DMSO nine times and screened in duplicates. Assay Ready Plates (ARPs; Corning 3764 BC black-walled, clear bottom plates) pre-drugged with test compounds (90nL sample in $100 \%$ DMSO per well dispensed using a Labcyte (ECHO 550) were prepared in the BSL-2 laboratory by adding $5 \mu \mathrm{L}$ assay media to each well. The plates were passed into the BSL-3 facility, where a $25 \mu \mathrm{L}$ aliquot of virus inoculated cells (4000 Vero E6 cells/well) was added to each well in columns 3-22. The wells in columns 23-24 contained virus infected cells only (no compound treatment). Prior to virus infection, a $25 \mu \mathrm{L}$ aliquot of cells was added to columns 1-2 of each plate for the cell only (no virus) controls. After incubating plates at $37^{\circ} \mathrm{C} / 5 \% \mathrm{CO}_{2}$ and $90 \%$ humidity for $72 \mathrm{~h}, 30 \mu \mathrm{L}$ of 
Cell Titer-Glo (Promega) was added to each well. Luminescence was read using a PerkinElmer Envision or BMG CLARIOstar plate reader following incubation at room temperature for $10 \mathrm{~min}$ to measure cell viability. Raw data from each test well was normalized to the average (Avg) signal of non-infected cells (Avg Cells; 100\% inhibition) and virus infected cells only (Avg Virus; $0 \%$ inhibition) to calculate \% inhibition of CPE using the following formula: \% inhibition $=100 *($ Test Cmpd - Avg Virus) $/$ (Avg Cells - Avg Virus). IC $_{50}$ values and curves were obtained using non-linear regression. The SARS CPE assay was conducted in BSL-3 containment with plates being sealed with a clear cover and surface decontaminated prior to luminescence reading. Reference compounds for CPE assay were made available by SRI.

\subsubsection{Method for measuring the cytotoxic effect of CLQ, CLBQ14, and CLCQ}

Compound cytotoxicity was assessed in a BSL-2 counter screen as follows using the Cell Titer-Glo Luminescent Cell Viability Assay (Severson et al., 2007). Host cells in media were added in $25 \mu 1$ aliquots (4000 cells/well) to each well of assay ready plates prepared with test compounds as above. Cells only (100\% viability) and cells treated with hyamine at $100 \mu \mathrm{M}$ final concentration ( $0 \%$ viability) serve as the high and low signal controls, respectively, for cytotoxic effect in the assay. DMSO was maintained at a constant concentration for all wells $(0.3 \%)$ as dictated by the dilution factor of stock test compound concentrations. After incubating plates at $37^{\circ} \mathrm{C} / 5 \% \mathrm{CO} 2$ and $90 \%$ humidity for $72 \mathrm{~h}, 30 \mu \mathrm{l}$ CellTiter Glo (CTG) (G7573, Promega) was added to each well. Luminescence was read using a BMG CLARIOstar plate reader following incubation at room temperature for $10 \mathrm{~min}$ to measure cell viability.

\subsubsection{ACE2 inhibitor screening assay}

An ACE2 Inhibitor screening assay kit with a fluorogenic substrate (Catalogue \#79923) was purchased from BPS Bioscience (San Diego, CA) and adapted to measure the exopeptidase activity of ACE2 in the presence and absence of inhibitors. The Fluorescence assay was performed using a black flat-bottom 96-well plate with a final reaction volume of $50 \mu \mathrm{L}$ following the manufacturer's instructions. We prepared $10 \mathrm{mM}$ stock solutions of the compounds in Dimethyl sulfoxide (DMSO). Next, we serially diluted the compounds in DMSO as follows: $100,50,10,1$, 0.5 , and $0.1 \mu \mathrm{M}$ for CLQ and CLBQ14; as well as $10 \mu \mathrm{M}$, and $1 \mu \mathrm{M}$ for CLCQ. All experiments were performed in triplicates. Each plate contained a positive control of enzyme-treated with vehicle alone $(2 \%$ DMSO), and a blank control with no enzyme. Briefly, each reaction contained $24 \mu \mathrm{L}$ of purified recombinant human ACE2 protein $(0.42 \mathrm{ng} /$ $\mu \mathrm{L}$ ) in ACE2 buffer, $1 \mu \mathrm{L}$ of compound at serially diluted concentrations, and $25 \mu \mathrm{L}$ ACE2 fluorogenic substrate. The total reaction volume was $50 \mu \mathrm{L}$. The reaction mixtures were protected from light and incubated for $2.5 \mathrm{~h}$ at room temperature $\left(22^{\circ} \mathrm{C}\right)$. Thereafter, the fluorescence intensities $\left(\lambda_{\text {Excitation }}=535 \mathrm{~nm}, \lambda_{\text {Emission }}=595 \mathrm{~nm}\right)$ were measured using a Beckman Coulter DTX880 multimode plate reader. A similar experiment was conducted to measure and compare the exopeptidase activity of ACE2 in the presence and absence of Zinc Chloride $\left(\mathrm{ZnCl}_{2}\right)$ alone, CLBQ14 alone, and $\mathrm{ZnCl}_{2}$ in combination with CLBQ14 at concentrations ranging from $100 \mu \mathrm{M}$ to $100 \mathrm{nM}$. $\mathrm{ZnCl}_{2}$ was serially diluted in water, and a positive control of enzyme-treated with vehicle alone (water for $\mathrm{ZnCl}_{2}$ only; DMSO for CLBQ14 alone; and water plus DMSO for $\mathrm{ZnCl}_{2}$ and CLBQ14) was carried out for this experiment. The background hydrolysis was subtracted, and the data were fitted to a four-parameter logistic (variable slope) equation using GraphPad prism software 8.4.3.

\subsubsection{The ACE2-Spike (RBD) protein interaction assay}

A Spike-ACE2 binding assay kit (Cat \# CoV-SACE2-1, Lot\# 062320 7066) was purchased from RayBiotech (Norcross, GA). The in vitro enzyme-linked immunoabsorbent assay (ELISA) was adapted and performed in a transparent flat-bottom 96-well plate. We prepared $10 \mathrm{mM}$ stock solutions of the compounds in Dimethyl sulfoxide (DMSO), with serially diluted the compounds in DMSO as follows: 100, 50, 10, 5, 1, 0.5, and $0.1 \mu \mathrm{M}$ for CLQ, CLBQ14, and CLCQ. All experiments were performed in triplicates. Each plate contained positive controls (1\% DMSO) and blank controls with no ACE2. Briefly, $1 \mu \mathrm{L}$ of serially diluted compounds were incubated with recombinant SARS-CoV-2 Spike receptor binding domain (RBD) protein, pre-coated on the 96 well plates in $49 \mu \mathrm{L}$ of $1 \mathrm{X}$ assay diluent buffer for $31 \mathrm{~min}$, at room temperature $\left(22^{\circ} \mathrm{C}\right)$ with shaking at $180 \mathrm{rpm}$. Next, we added $50 \mu \mathrm{L}$ of ACE2 protein in $1 \mathrm{X}$ assay diluent buffer into the 96 well plate and incubated for $2.5 \mathrm{~h}$ at room temperature $\left(22{ }^{\circ} \mathrm{C}\right)$ with shaking at $180 \mathrm{rpm}$. Thereafter, the solution was discarded and the plate was washed four times with $300 \mu \mathrm{L}$ of $1 \mathrm{X}$ wash buffer, followed by the addition of the detection antibody (anti-ACE2 goat antibody). The reaction was allowed to go on for $1 \mathrm{~h}$ at room temperature $\left(22^{\circ} \mathrm{C}\right)$ with shaking at $180 \mathrm{rpm}$. Then, the solution was discarded, and the wash step was repeated as described above. Next, the HRPconjugated anti-goat IgG was added to each well, and the reaction plate was further incubated for $1 \mathrm{~h}$ at room temperature $\left(22^{\circ} \mathrm{C}\right)$ with shaking at 180rpm. Again, the solution was discarded, and the wash step was repeated as described above. Then, $100 \mu \mathrm{L}$ of 3,3',5,5' -tetramethylbenzidine (TMB) one-step substrate was added to each well, and the reaction mixtures were incubated in the dark at room temperature $\left(22^{\circ} \mathrm{C}\right)$ with shaking at $180 \mathrm{rpm}$ for an additional $30 \mathrm{~min}$ and then stopped by the addition of $50 \mu \mathrm{L}$ stop solution. The absorbance was read at $405 \mathrm{~nm}$ using a Beckman Coulter DTX880 multimode plate reader. The background hydrolysis was subtracted, and the data were fitted to a special bellshaped dose-response curve equation using GraphPad prism software 8.4.3.

\section{Results}

\subsection{Efficacy of Clioquinol (CLQ) and analogues against SARS-CoV-2 infection -induced cytopathic effect (CPE) in Vero E6 cells}

In our efforts to identify inhibitors of SARS-CoV-2 infection for the potential treatment of COVID-19, we evaluated the in vitro antiviral activity of CLQ, and two of its derivatives, CLBQ14 and CLCQ, using a standard luminescent-based high-throughput screening (HTS) platform (Maddox et al., 2008; Severson et al., 2007) for SARS-CoV-2 infectio$\mathrm{n}$-induced CPE in African Green Monkey Kidney Vero E6 cells. We found that all three compounds inhibited SARS-CoV-2 infection-induced CPE in vitro with $50 \%$ Inhibitory Concentration $\left(\mathrm{IC}_{50}\right.$ ) values in the low micromolar concentration (Figure 1). Amongst all three analogues tested, CLQ displayed the most potent antiviral activity in the CPE assay (Figure 1). Compared to its counterparts, CLBQ14 exhibited the highest maximum inhibition at about $102.96 \%$ inhibition at $30 \mu \mathrm{M}$ (Table 1 ). In addition, we compared the antiviral effects of CLBQ14 and its analogues with five other known inhibitors of SARS-CoV-2 in vitro: Chloroquine, Hydroxychloroquine, Remdesivir, Aloxistatin and Calpain Inhibitor IV (Figure 2). The dose-response curves of the CLQ, CLBQ14, CLCQ and the reference compounds mentioned above were determined at multiplicities of infection (MOI) of about 0.002 (Figure 2). We found that the IC 50 for CLQ $(12.62 \mu \mathrm{M})$, and its analogues [(CLBQ14, 14.69 $\mu \mathrm{M})$ and (CLCQ, $16.30 \mu \mathrm{M})]$ were slightly lower than the $\mathrm{IC}_{50}$ of Aloxistatin $(16.72 \mu \mathrm{M})$; but moderately higher than Chloroquine $(1.10 \mu \mathrm{M})$, Hydroxychloroquine $(5.04 \mu \mathrm{M})$, Remdesivir $(4.42 \mu \mathrm{M})$, and Calpain Inhibitor IV $(0.41 \mu \mathrm{M})$ (Table 2). These results suggest a potentially new mechanism of action for CLQ and its congeners. Notably, this is the first report to our knowledge, revealing that CLQ and its analogues effectively inhibit the novel SARS-CoV-2 infection-induced CPE.

\subsection{Cytotoxicity effects of CLQ and analogues in Vero E6 cells}

We determined the preliminary cytotoxicity of CLQ and its analogues (CLBQ14 and CLCQ), using a Cell Titer-Glo Luminescent Cell Viability Assay (Severson et al., 2007). We assessed the cytotoxic effects of the various compounds in Vero E6 cells and observed that, the $50 \%$ cytotoxic concentration $\left(\mathrm{CC}_{50}\right)$ of $\mathrm{CLQ}$ and its derivatives were all greater than 

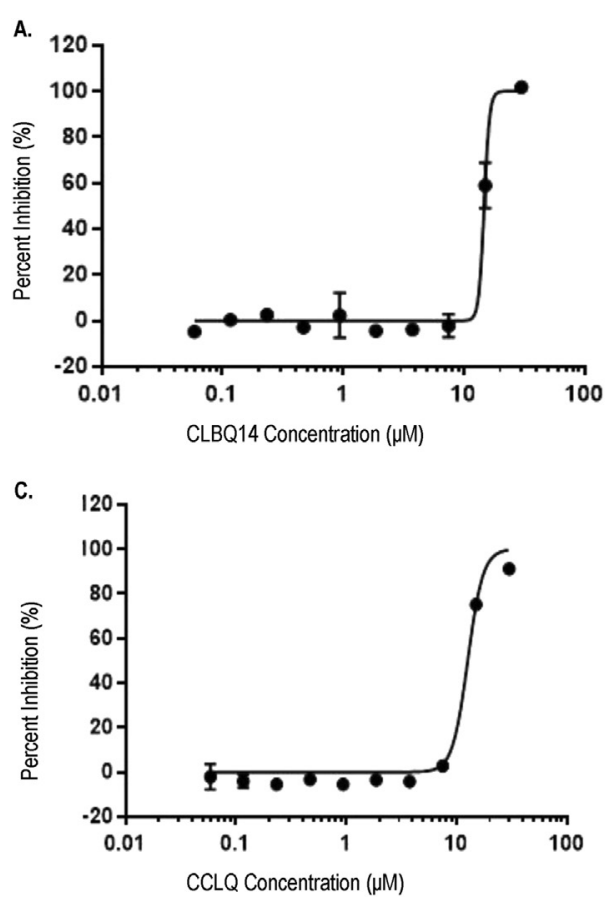

B.

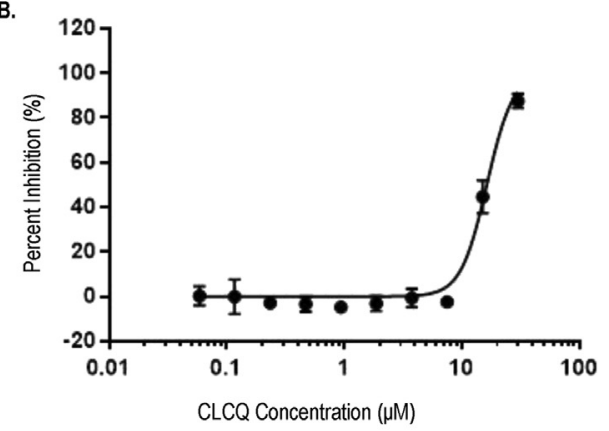

Figure 1. Efficacy of Clioquinol (CLQ) and Analogues against SARS-CoV-2 induced Cytopathic Effect (CPE) in Vero E6 cells: A. CLBQ14, B. CLCQ, and C. CLQ.

$30 \mu \mathrm{M}$. However, in comparison to the other reference compounds tested, CLQ and its analogues displayed lower percent minimum viability at higher concentrations. On the other hand, we observed similar percent maximum viability for CLQ pharmacophore and the other reference compounds at lower concentrations (Table 3). This suggests that, the cytotoxic effects may not be a concern at lower concentrations of CLQ and its analogues. Additional concentrations need to be tested in future studies to determine the actual $\mathrm{CC}_{50}$ value (Table 3 ).

\subsection{Effects of CLQ and its analogues on rhACE2 exopeptidase activity}

We determined the effect of CLQ, CLBQ14 and CLCQ on the exopeptidase activity of rhACE2 using an adapted fluorometric assay

Table 1. Chemical Structure and Activity of Clioquinol (CLQ) and Analogues against SARS-CoV-2 induced Cytopathic Effect (CPE) in Vero E6 Cells.

\begin{tabular}{|c|c|c|c|c|}
\hline Inhibitor ID & Screen ID & Chemical Structure & $\mathrm{IC}_{50}(\mu \mathrm{M})$ & Maximum Inhibition at $30 \mu \mathrm{M}(\%)$ \\
\hline CLBQ14 & MDXC19T001 & $\mathrm{Cl}$ & 14.69 & 102.96 \\
\hline CLCQ & MDXC19T002 & $C$ & 16.30 & 89.78 \\
\hline CLQ & MDXC19T003 & & 12.62 & 91.78 \\
\hline
\end{tabular}




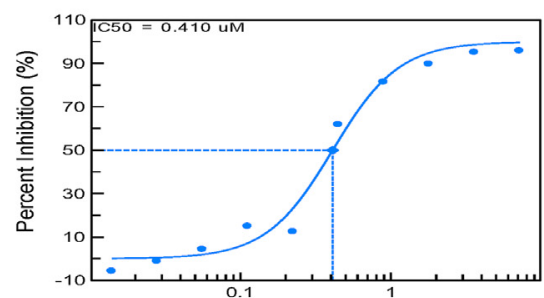

Calpain Inhibitor IV Concentration ( $\mu \mathrm{M})$

C.

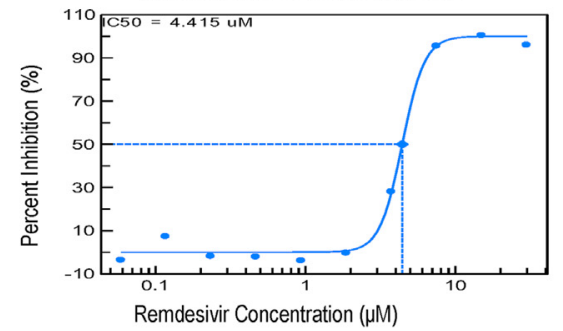

E.

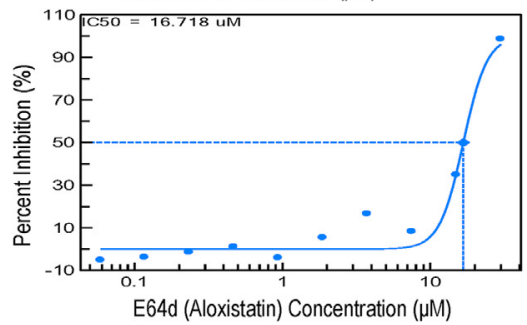

B.

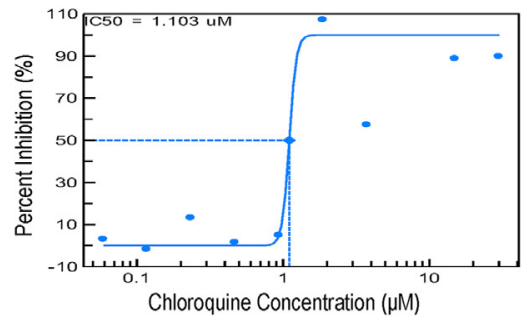

D.

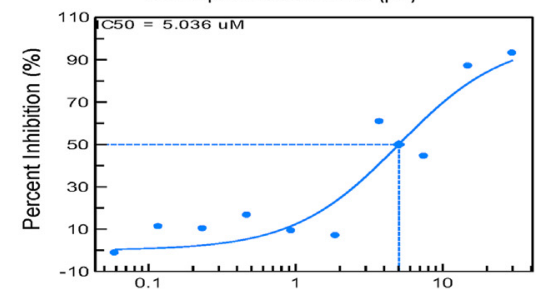

Hydroxychloroquine Concentration ( $\mu \mathrm{M})$

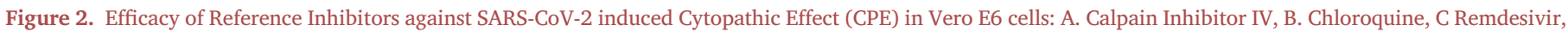
D. Hydroxychloroquine, and E. E64d (Aloxistatin).

(BPS Bioscience). We found that all three compounds inhibited rhACE2 activity with similar IC $_{50}$ values in the low micromolar concentration, with CLQ being the most potent amongst all three analogues tested at $\mathrm{IC}_{50}$ of $5.36 \mu \mathrm{M}$ (Table 4). To our knowledge, these results revealed for the first time that rhACE2 is a biochemical target of CLQ and its analogues. Because the known metal cofactor for ACE2 is Zinc (Towler et al., 2004; Vickers et al., 2002), using the same fluorometric assay described above in the methods section, we further assessed the exopeptidase activity of rhACE2 in the presence of Zinc Chloride $\left(\mathrm{ZnCl}_{2}\right)$ alone, CLBQ14 alone and $\mathrm{ZnCl}_{2}$ in combination with CLBQ14 at concentrations ranging from $100 \mu \mathrm{M}$ to $100 \mathrm{nM}$. In the presence of $\mathrm{ZnCl}_{2}$ alone, rhACE2 displayed increasing exopeptidase activity. On the other hand, in the presence of $\mathrm{ZnCl}_{2}$ in combination with CLBQ14, we observed an increased shift in $\mathrm{IC}_{50}$ value by over 28 fold compared to CLBQ14 alone (Figure 3). Interestingly, this data reveals that increasing concentrations of $\mathrm{ZnCl}_{2}$ titrates the inhibitory effect of CLBQ14 on rhACE2 from

Table 2. Chemical Structure and Activity of Reference Inhibitors against SARS-CoV-2 induced Cytopathic Effect (CPE) in Vero E6 Cells.

\begin{tabular}{|c|c|c|c|c|c|}
\hline Inhibitor ID & Screen ID & Chemical Structure & $\mathrm{IC}_{50}(\mu \mathrm{M})$ & Maximum Inhibition (\%) & Concentration at Maximum \% Inhibition $(\mu \mathrm{M})$ \\
\hline Calpain Inhibitor IV & АВ01968659 & & 0.41 & 95.75 & 7.17 \\
\hline Chloroquine & AB00053436 & & 1.10 & 111.08 & 7.50 \\
\hline Remdesivir & АВ01952209 & & 4.42 & 100.27 & 15.00 \\
\hline Hydroxychloroquine & AB00053257 & & 5.04 & 93.14 & 30.00 \\
\hline E64d (Aloxistatin) & AB01955411 & & 16.72 & 98.55 & 30.00 \\
\hline
\end{tabular}


Table 3. Cytotoxicity of Clioquinol (CLQ) and analogues in Vero E6 cells, in comparison to reference inhibitors of SARS-CoV-2.

\begin{tabular}{|c|c|c|c|c|c|}
\hline Inhibitor ID & $\begin{array}{l}\text { Cytotoxicity } \\
\mathrm{CC}_{50}(\mu \mathrm{M})\end{array}$ & $\begin{array}{l}\text { Minimum } \\
\text { Viability (\%) }\end{array}$ & $\begin{array}{l}\text { Concentration at } \\
\text { Minimum \% Viability }(\mu \mathrm{M})\end{array}$ & $\begin{array}{l}\text { Maximum } \\
\text { Viability (\%) }\end{array}$ & $\begin{array}{l}\text { Concentration at } \\
\text { Maximum \% Viability }(\mu \mathrm{M})\end{array}$ \\
\hline CLBQ14 & $>30.00$ & 53.50 & 15.00 & 107.88 & 0.12 \\
\hline CLCQ & $>30.00$ & 60.82 & 15.00 & 101.51 & 0.06 \\
\hline CLQ & $>30.00$ & 61.83 & 30.00 & 105.82 & 0.23 \\
\hline Calpain Inhibitor IV & $>7.17$ & 98.29 & 3.59 & 104.99 & 0.22 \\
\hline Chloroquine & $>30.00$ & 95.63 & 15.00 & 106.60 & 0.06 \\
\hline Remdesivir & $>30.00$ & 97.49 & 3.75 & 104.49 & 0.06 \\
\hline Hydroxychloroquine & $>30.00$ & 96.88 & 3.75 & 103.65 & 0.06 \\
\hline E64d (Aloxistatin) & $>30.00$ & 100.06 & 15.00 & 112.76 & 0.12 \\
\hline
\end{tabular}

Table 4. Activity of Clioquinol (CLQ) and analogues against ACE2 exopeptidase activity and ACE2 and SARS-CoV-2 Spike (RBD) protein interaction.

\begin{tabular}{|c|c|c|c|}
\hline \multirow[t]{2}{*}{ Inhibitor ID } & \multicolumn{3}{|l|}{$\mathrm{IC}_{50}(\mu \mathrm{M})$} \\
\hline & ACE2 Exopeptidase Activity Assay & Spike (RBD)-ACE2 Interaction Assay $\left(\mathrm{IC}_{50 \_1}(\mu \mathrm{M})\right)$ & Spike (RBD)-ACE2 Interaction Assay $\left(\mathrm{IC}_{50 \_2}(\mu \mathrm{M})\right)$ \\
\hline CLBQ14 & 5.55 & 2.76 & 3.06 \\
\hline CLCQ & $<10$ & 1.74 & 1.91 \\
\hline CLQ & 5.36 & 0.85 & 18.15 \\
\hline CLBQ14 and $\mathrm{ZnCl}_{2}$ & 159.00 & ND & ND \\
\hline $\mathrm{ZnCl}_{2}$ & ND & ND & ND \\
\hline
\end{tabular}

* Higher Concentrations need to be conducted to determine $\mathrm{IC}_{50}$.

concentrations ranging from above $5-10 \mu \mathrm{M}$, consistent with previous reports of the required optimal concentration range of Zinc for the exopeptidase activity of ACE2 (Vickers et al., 2002). Taken together, these preliminary results reveal a new pharmacologic mode of action and novel target for CLQ and its analogues.

\subsection{Effects of CLQ and its analogues on rhACE2 and Spike (RBD) protein interaction}

The interaction of the human ACE2 receptor with SARS-CoV-2's Spike protein receptor binding domain is a critical first step in the process required for viral entry into host cells (Wrapp et al., 2020; Yan et al., 2020; Wang et al., 2020; Walls et al., 2020). Using an adapted in vitro enzyme-linked immunoabsorbent assay (ELISA) (RayBiotech, 2020), we evaluated the effect of CLQ, CLBQ14 and CLCQ on the binding affinity of rhACE2 and RBD of the $S$ protein at concentrations ranging from $100 \mu \mathrm{M}$ to $100 \mathrm{nM}$. Surprisingly, we observed a unique bell-shaped dose-response curve for all three compounds with higher inhibition of ACE2-Spike (RBD) protein interaction at lower compound concentrations compared

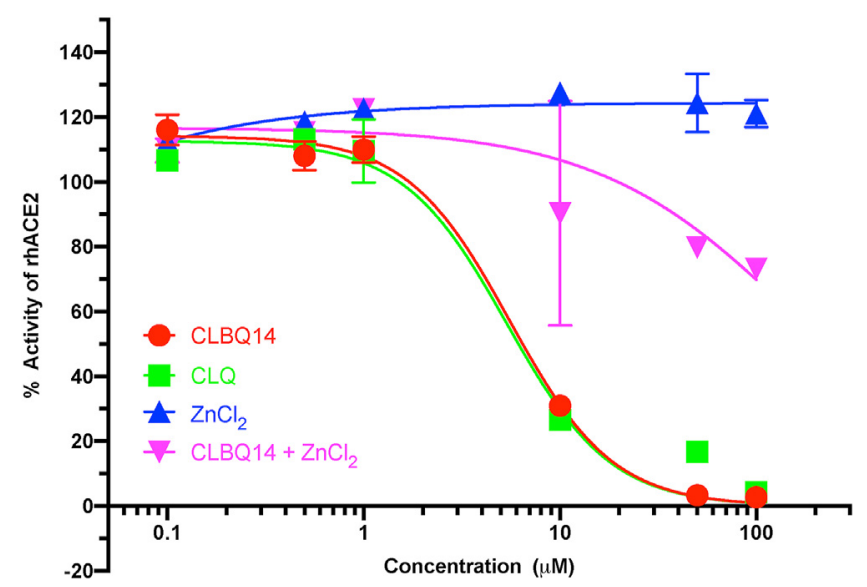

Figure 3. Effect of Clioquinol (CLQ) and Analogues against ACE2 Exopeptidase Activity: A. CLBQ14 (Circles - red), B. CLQ (Squares - green), and C. $\mathrm{ZnCl}_{2}$ (Triangle - blue), and D. CLBQ14 and $\mathrm{ZnCl}_{2}$ (Inverted Triangles - magenta). to higher concentrations (Figure 4). The bell-shaped curve generated two $\mathrm{IC}_{50}$ values $\left(\mathrm{IC}_{50 \_1}\right.$ and $\mathrm{IC}_{50 \_}$), as shown in Table 4 . We found that all three compounds had similar $\mathrm{IC}_{50}$ values in the low micromolar concentration ranging from $0.85 \mu \mathrm{M}$ to $2.76 \mu \mathrm{M}$ for $\mathrm{IC}_{50} 1$; however, CLQ displayed a higher $\mathrm{IC}_{50 \_2}$ at $18.15 \mu \mathrm{M}$ (Table 4). The unconventional dose response curve observed in this interaction assay could be an indicator of additional binding site(s) and/or target(s) for the CLQ pharmacophore, such as other sites on ACE2 or the Spike (RBD) protein. Again, these findings are the first report to reveal that CLQ and its analogues inhibit and interfere with the binding between human ACE2 receptor and SARS-CoV-2 Spike RBD protein in vitro. These results suggest that the CLQ and its derivatives might be promising leads for the clinical development of novel SARS-CoV-2 entry inhibitors and potential COVID-19 therapeutics.

\section{Discussion}

Given the ongoing COVID-19 pandemic and the emerging virulence of novel SARS-CoV-2 strains, there is an urgent need to accelerate the development of effective therapeutic agents as countermeasures against this pathogen. In this study, we applied three independent approaches to investigate the possibility of CLQ and its analogues as potential inhibitors of the SARS-CoV-2 infection in vitro and gathered strong evidence that these pharmacophores are promising leads for the discovery and preclinical development of novel SARS-CoV-2 entry inhibitors and potential COVID-19 therapeutics. To our knowledge, this is the first report revealing rhACE2 as a novel target for CLQ and its analogues, a new pharmacologic mode of action for an old antibacterial. Taken together, our in vitro findings that CLQ significantly inhibited the binding of rhACE2 receptor with SARS-CoV-2 Spike (RBD) protein and SARS-CoV-2 infection-induced CPE, strongly supports the notion that CLQ and its congeners could be potential drugs and/or chemical probes in the development of countermeasures against viral entry into host cells.

The availability of simple, rapid, cellular high throughput screening and well-characterized biochemical assays enabled us to quickly discover novel inhibitors of SARS-CoV-2 infection in vitro. We successfully identified and characterized CLQ, a known metal chelator, and Zinc ionophore as a novel inhibitor of SARS-CoV-2 infection-induced CPE. Using two structural analogues of CLQ (CLBQ14 and CLCQ) in hand, we were 
A.

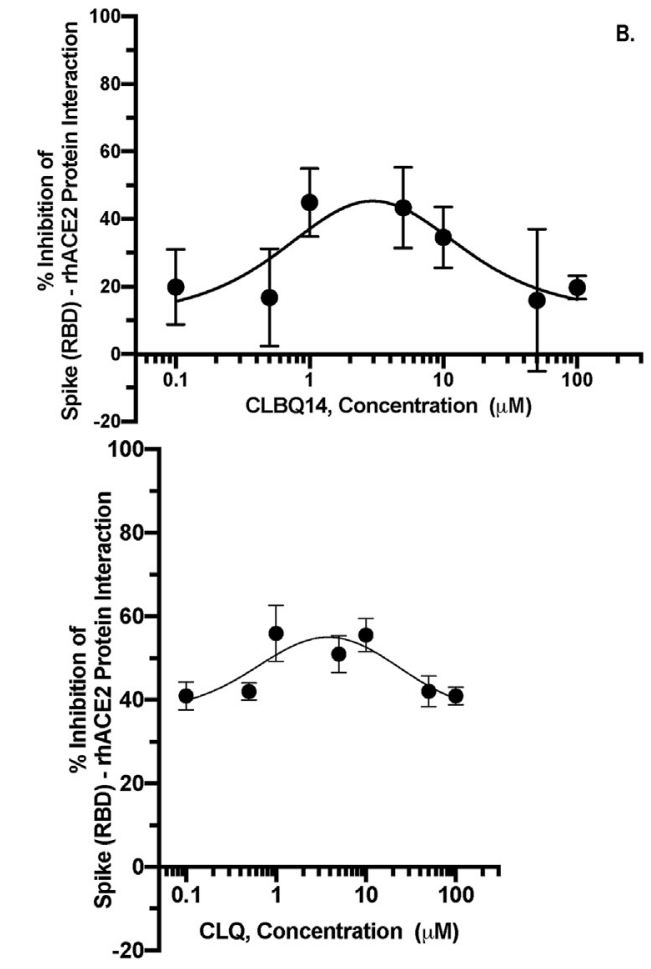

B.

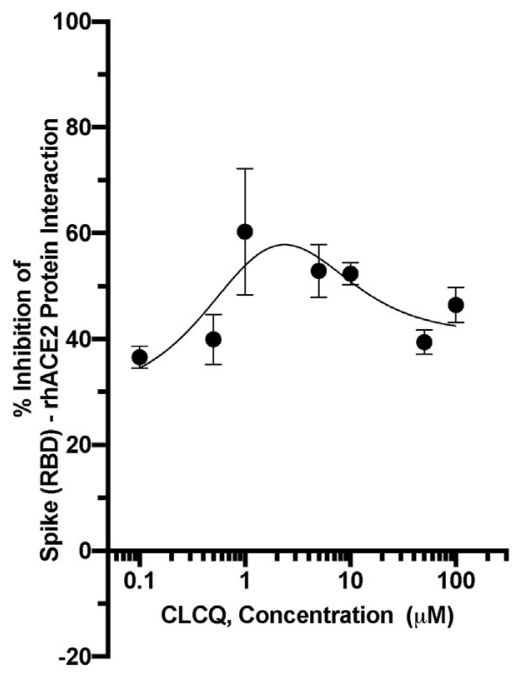

Figure 4. Inhibition of ACE2 and SARS-CoV-2 Spike (RBD) protein interaction by Clioquinol (CLQ) and analogues: A. CLBQ14, B. CLCQ, and C. CLQ.

able to further explore the impact of the active CLQ pharmacophore on the novel coronavirus infection, the exopeptidase activity of rhACE2, and the interaction of rhACE2 with SARS-CoV-2 Spike (RBD) protein, all critical steps/processes in the pathogenesis of COVID-19. All three analogues displayed similar potent inhibition in the low micromolar range against SARS-CoV-2 infection-induced CPE, rhACE2 activity, and its interaction with Spike protein. In this study, we also compared the doseresponse curves of antiviral effects of CLQ and its analogues with five other known inhibitors of SARS-CoV-2 in vitro: Chloroquine, Hydroxychloroquine, Remdesivir, Aloxistatin, and Calpain Inhibitor IV and found that CLQ's potency was better and comparable to Aloxistatin; but had lower efficacy than the other reference inhibitors (Table 2). It is important to note that the Vero E6 cells used for the SARS-CoV-2 infectioninduced CPE assay were first sorted by flow cytometry by SRI for selection of cells that had higher levels of ACE2 expression to increase the efficiency of infection. Therefore, the observed IC 50 values may be higher than the actual $\mathrm{IC}_{50}$ values in cells that do not have high levels of ACE2 expression. Moreover, we observed that the $\mathrm{IC}_{50}$ values of the compounds in the biochemical assays were much lower than the $\mathrm{IC}_{50}$ in the cellular antiviral assay. We also assessed the cytotoxic effects of the compounds in Vero E6 cells and observed that CLQ and its analogues displayed lower percent minimum viability at higher concentrations compared to the other reference compounds tested. However, we observed similar percent maximum viability for CLQ pharmacophore and the other reference compounds at lower concentrations (Table 3). This suggests that the cytotoxic effects may not be a concern at lower concentrations of CLQ and its analogues. In addition, the observed $\mathrm{IC}_{50}$ values for inhibition of rhACE2 exopeptidase activity and rhACE2-RBD interaction were in the low micromolar range, suggesting that we may need lower concentrations for in vivo activity. Furthermore, we have other preliminary cytotoxicity results from prior in vivo studies on CLQ and its analogues that reveal no significant toxicity at much lower concentrations below the nanomolar range (unpublished data). Therefore, additional in vivo cytotoxicity studies for Vero E6 cells should be conducted at a wider range of concentrations.

Throughout our study, we consistently observed a correlation between the high potency of CLQ compared to its other two analogues in the antiviral screen, inhibition of rhACE2 metalloprotease activity, and its ability to disrupt the binding of rhACE2 with SARS-CoV-2 Spike (RBD) protein. Amongst all three compounds, CLQ displayed the highest potency in all three independent assays, except for $\mathrm{IC}_{50} 2$, hence validating its potential as a therapeutic option for the treatment of COVID-19. Clioquinol and its derivatives belonging to 8-hydroxyquinoline structural class have been investigated extensively in basic, translational, and clinical studies because of their multiple activities as metal chelators and Zinc ionophores, modulating underlying molecular and physiologic switches required for metal homeostasis in vivo (You et al., 2018; Bednarz-Prashad and John, 1983; Auld et al., 1974; Olaleye et al., 2011; Darby and Nathan, 2010; Tavares et al., 2018, 2020; Bohlmann et al., 2018; Schimmer et al., 2012; Ayton et al., 2015; Cherny et al., 2012; Lannfelt et al., 2008; Ritchie et al., 2003; Adlard et al., 2008; Shi et al., 2020; Perez et al., 2019; McInerney et al., 2018; Yu et al., 2009; Ding et al., 2005) Haase et al., 2008; Lind et al., 2009; Andersson et al., 2009; Ding et al., 2008). Previously, CLQ was used to treat bacterial infections (Cahoon, 2009); however, it was withdrawn from the clinic because of untoward effects of subacute myelo-optic neuropathy (SMON) mostly experienced in Japan in the 1950's (Perez et al., 2019; Cahoon, 2009; Kono, 1971). More recent studies revealed that SMON might be due to other biologic factors and/or pharmacogenetics primarily linked to the Japanese population (Perez et al., 2019; Cahoon, 2009; Meade, 1975). Currently, in the clinic, CLQ is approved for use in combination with other agents for the treatment of inflammatory skin disorders and fungal infections in some countries (You et al., 2018; Mao and Schimmer, 2008). More recently, CLQ and its newer structural derivatives have gained 
renewed interest as potential drugs for the development of therapeutics for neurodegenerative diseases, cancer, and infectious diseases (You et al., 2018; Bednarz-Prashad and John, 1983; Auld et al., 1974; Olaleye et al., 2011; Darby and Nathan, 2010; Tavares et al., 2018, 2020; Bohlmann et al., 2018; Schimmer et al., 2012; Ayton et al., 2015; Cherny et al., 2012; Lannfelt et al., 2008; Ritchie et al., 2003; Adlard et al., 2008; Shi et al., 2020; Perez et al., 2019; McInerney et al., 2018; Yu et al., 2009; Ding et al., 2005) Haase et al., 2008; Lind et al., 2009; Andersson et al., 2009; Ding et al., 2008). Furthermore, in previous studies, Olaleye O. et al., serendipitously discovered CLBQ14, the bromine analogue of CLQ, and characterized CLQ and additional derivatives as potent inhibitors of replicating and non-replicating Mycobacterium tuberculosis, using an HTS assay designed to identify novel metalloprotease inhibitors (Olaleye et al., 2011). Altogether, the plethora of evidence on the broad pharmacologic spectrum of activity and metal-chelation propensity of CLQ pharmacophore, combined with its extensive clinical investigational profile, makes this structural class attractive and promising for targeting ACE2, the important Zinc metalloenzyme and essential cellular receptor for SARS-CoV-2 entry into host cells (Wrapp et al., 2020; Yan et al., 2020; Wang et al., 2020; Walls et al., 2020).

ACE2, a carboxypeptidase, is a known type I integral membrane protein made up of about 805 amino acids belonging to the large family of Zinc metalloproteases with a high level of structural homology for a catalytic motif, containing one characteristic HEXXH + E Zinc-binding consensus sequence and binding sites for inhibitor or specific substrates respectively (Towler et al., 2004). According to earlier reports by Towler et al. the first crystalline structures of the metallopeptidase domain of ACE2 revealed "a large inhibitor-dependent hinge bending movement of one catalytic subdomain relative to the other that brings important amino acid residues into position for catalysis," similar to observed subdomains on other Zinc metalloproteases respectively (Towler et al., 2004). The residues critical for coordinating the binding of Zinc to ACE2 are $\mathrm{His}^{374}$, $\mathrm{His}^{378}$, and $\mathrm{Glu}^{402}$, according to earlier x-ray structures (Towler et al., 2004). Moreover, ACE2 is activated by monovalent anions and is also known to contain an inhibitor-specific anion binding site (Towler et al., 2004; Vickers et al., 2002). The reported optimal metalloprotease activity of recombinant soluble human ACE2 was found to be in the presence of $10 \mu \mathrm{M} \mathrm{ZnCl}_{2}$ (Vickers et al., 2002). This is consistent with our findings of rhACE2 exopeptidase activity assay in the presence of $\mathrm{ZnCl}_{2}$. In the presence of the newly identified potent metalloprotease inhibitors (CLQ or CLBQ14 alone), we observed a significantly decreased exopeptidase activity for ACE2 in the low micromolar concentrations (Figure 4). However, we found an increased shift in $\mathrm{IC}_{50}$ values when we assessed exopeptidase activity in the presence of $\mathrm{ZnCl}_{2}$ in combination with CLBQ14 by over 28 fold compared to CLBQ14 alone (Figure 3), suggesting that CLBQ14 might be working through Zinc chelation, interaction and/or coordination. Our findings not only revealed a novel target (rhACE2) and mechanism of action for the CLQ pharmacophore; but also provides insight into potential reversibility of inhibition and one or more probable mode(s) of inhibition: 1) The concentration of CLBQ14 is titrated with excess $\mathrm{ZnCl}_{2}$, thus pre-occupied and unavailable to inhibit rhACE2 exopeptidase activity; and/or 2) potential competition for the similar binding sites on rhACE2. Additional mechanistic kinetic studies will be required to ascertain these notions.

Moreover, as mentioned earlier, ACE2 plays an essential role in the regulation of cardiovascular and respiratory physiology (Kuba et al., 2005; Towler et al., 2004). Its characterization as the functional host receptor for entry of the novel SARS-CoV-2 into human cells (Wrapp et al., 2020; Yan et al., 2020; Wang et al., 2020; Walls et al., 2020) has raised concerns about the potential impact of newly discovered ACE2 inhibitors on cardiovascular and respiratory physiology (South et al., 2020; Nishiga et al., 2020; Imai et al., 2005). Recent studies have also shown that ACE2 plays a key role in protecting the lungs from ARDS (Nishiga et al., 2020; Imai et al., 2005), a severe complication of COVID-19 disease (Huang et al., 2020). Therefore, one has to proceed cautiously when targeting ACE2 (South et al., 2020); without permanently inactivating its exopeptidase or other cellular functions to avoid potential adverse effects to the heart and/or lung function. Our lead compound CLQ is a weak metal chelator and Zinc ionophore that can shuttle free Zinc across the membrane (Yu et al., 2009; Colvin et al., 2008). Because of these properties, CLQ may temporarily or reversibly affect ACE2 function and prevent its interaction with SARS-CoV-2 RBD protein; without permanently inhibiting its essential exopeptidase function. Because rhACE2 is a novel host target for CLQ and its analogues, the potential effect of CLQ inhibition on heart and lung function needs to be further explored in vivo and pre-clinical studies.

The crystal structure of full-length human ACE2 revealed that the RBD on SARS-CoV-2 S1 binds directly to the metallopeptidase domain (MPD) of the ACE2 receptor (Wrapp et al., 2020; Yan et al., 2020), which consists of amino acid residues that coordinate Zinc, providing further support for the utility of Zinc chelators and/or ionophores such as CLQ and its congeners, as promising inhibitors of interaction and viral entry inhibitors. Using a sensitive ELISA, we found that CLQ and its analogues potently disrupt the interaction of ACE2 and Spike (RBD) protein, with CLQ being the most potent. This supports our findings that CLQ and its derivatives bind to ACE2 and inhibits its exopeptidase activity. Interestingly unlike the CLQ pharmacophore, other studies revealed that (S,S)-2-\{1-Carboxy-2-[3-(3, 5-dichloro-benzyl)-3H-imidazol-4-yl]-ethylamino\}-4-methyl-pentanoic acid (MLN-4760), a known potent inhibitor of ACE2 exopeptidase activity, belonging to a different chemical class, does not disrupt ACE2-Spike interaction in coronaviruses, SARS-CoV, SARS-CoV2, and NL63S (Nami et al., 2020; Mathewson et al., 2008) as its binding site on ACE2 is different from the site where RBD interacts with ACE2 (Towler et al., 2004; Nami et al., 2020; Li et al., 2005). However, CLQ seems to affect ACE2 by reversibly chelating its Zinc ion, which is essential for ACE2 activity, as well as interfere with ACE2-RBD interaction. Although Zinc is essential for stabilizing protein structures and altering the substrate affinity of different metalloproteins (Ding et al., 2005; Cox and McLendon, 2000), the effects of Zinc chelation on the molecular structure of ACE2 and its effects on its binding to the SARS-CoV-2 remains to be tested. Moreover, earlier molecular and structural studies also revealed that mutations in the catalytic site required for exopeptidase activity of ACE2 had no effect on Spike RBD binding to ACE2 (Towler et al., 2004). Howbeit, the unconventional dose-response bell shaped curve that we observed in our studies suggests that there may be additional binding sites and/or modes of action for CLQ and its congeners, resulting in the potent inhibition of interaction at lower micromolar concentrations; compared to higher concentrations. Although CLQ was found to be the most potent amongst all 3 analogues, except for $\mathrm{IC}_{50}$ 2, preliminary structure activity relationship studies (SAR) revealed that the other two derivatives are comparable to CLQ, as they both show potent inhibition of rhACE2-RBD interaction, as well as inhibition of antiviral and anti-rhACE2 activity. Therefore, providing alternative analogues that might not have the same adverse effects experienced with CLQ in the past, potentially alleviating some of the concerns with CLQ. Additional biochemical and structural studies are required to explore other possible mechanisms of action such as competition or interaction of CLQ with RBD for binding to the MPD of ACE2, thereby preventing Zinc chelation and ionophore activity of CLQ. Future X-ray structures could help to better understand the mode of inhibition of this pharmacophore and the rational design of more potent drugs.

The strength of our study includes the use of a rapid multi-prong approach via three sensitive independent assays to identify and characterize an existing clinical drug as a novel inhibitor of SARS-CoV-2 infection in vitro. In addition, the availability of structural analogues of CLQ, made possible a preliminary SAR, which revealed similarity between the $\mathrm{IC}_{50}$ values of CLQ and its structural analogues. However, our study has some limitations, such as the use of Vero E6 cells that were selected for high expression of ACE2 in the antiviral assay, a HTS designed to rapidly screen for inhibitors of infection-induced CPE. An additional limitation is that the amount of Zinc in the purified rhACE2 supplied from BPS and RayBiotech assays was unknown. Future metal 
dependent studies with apoenzymes will be required to determine the amount of Zinc. Considering that CLQ is a known Zinc chelator and ionophore, an understanding of the physiologic amount of Zinc required for inhibition will be critical for optimal efficacy. Therefore, for these two limitations, the measured $\mathrm{IC}_{50}$ values for the compounds may not be representative of the actual in vitro $\mathrm{IC}_{50}$, which may be lower. However, the remarkable consistency in the observed strong correlation between CLQ, and its congener's antiviral activity, in vitro rhACE2, inhibition and disruption of ACE2-RBD protein interaction, reduce these concerns.

\section{Conclusion and significance}

The impact of the COVID-19 pandemic on human health, healthcare systems, and the global economy (Chaudhry et al., 2020) has imposed an urgent call/pressing need for the development of novel antivirals. Rapid clinical development of anti-COVID19 treatments could be accelerated by the discovery of repurposed clinically approved drugs with new mechanisms of action and/or multiple cellular targets that could potentially disrupt viral pathogenesis/survival and/or prevent the viral entry/interaction with host receptor ACE2. The body of evidence on the broad pharmacologic spectrum of activity, metal-chelation propensity, and Zinc ionophore activity of CLQ pharmacophore, combined with its extensive clinical investigational profile, makes this structural class attractive and promising drugs for targeting rhACE2. Using a multi-prong approach, we discovered and characterized CLQ, a clinical drug, and two of its analogues (CLBQ14 and CLCQ) as potent inhibitors of SARS-CoV-2 infection-induced CPE in vitro; rhACE2 metalloprotease activity; and the binding of rhACE2 with SARS-CoV-2 Spike (RBD) protein. Altogether, these novel findings provide insights into a new mode of action and molecular target(s) for CLQ and its derivatives. Thus, validating this structural class as promising leads for clinical development of novel SARS-CoV-2 entry inhibitors and potential COVID-19 therapeutics. Because rhACE2 is a host target, it reduces the concerns for the development of drug resistance, which is usually seen with drugs that target viral genes. Further SAR, computational/molecular modeling, and $\mathrm{X}$-crystal structure studies will aid the rational design and synthesis of more potent inhibitors in the CLQ-containing, 8-hydroxylquinoline structural class. Our studies not only provide an additional new drug class with Zinc chelating and ionophore properties in the pipeline for the urgent quest for therapeutic management for anti-COVID-19 but also suggests that there could be the potential physiologic relevance of Zinc homeostasis in SARS-CoV-2 infection and COVID-19 pathogenesis. In addition, CLQ and its derivatives could be used as chemical probes to study the biology of host-pathogen interaction in the context of SARS-CoV-2 infections. In the future, the functional importance of molecular and cellular regulation of host and viral Zinc-dependent genes/proteins in SARS-CoV-2 pathogenesis and survival may be better understood and targeted with available Zinc chelators, ionophores, and transporters. Moreover, unlike MLN-4670, another known ACE2 inhibitor (Towler et al., 2004; Nami et al., 2020; Mathewson et al., 2008), our results not only show that CLQ and its analogues inhibit rhACE2 with antiviral activity but also suggests that CLQ pharmacophore, potently disrupts the interaction of rhACE2 and Spike (RBD) protein. To this end, we provide strong cellular and biochemical evidence supporting the notion that CLQ, CLBQ14, and CLCQ, could serve as a potential lead series for the pre-clinical development of new anti-COVID-19 treatments. The expectation is that the development of new anti-COVID-19 treatments with dual activity against viral and host entry target could help combat the issue of emerging drug-resistant strains, drug-drug interactions, reduction in the cost of treatment, possibly increase patient compliance and improve patient care as well as reduce the mortality rate due to SARS-CoV-2 infection. Therefore, we propose pharmacologic and clinical studies to further explore CLQ and/or its derivatives as treatment options in the toolbox for combating this novel coronavirus and be evaluated in conjunction with other available therapeutics to reduce COVID-19 morbidity and mortality as well as a potential drug to drug interactions (Zhang et al., 2017; Capel et al., 2015; Plasencia-Garcia et al., 2020; Roden et al., 2020) encountered with other drugs.

\section{Declarations}

\section{Author contribution statement}

Omonike A. Olaleye: Conceived and designed the experiments; Performed the experiments; Analyzed and interpreted the data; Contributed reagents, materials, analysis tools or data; Wrote the paper.

Manvir Kaur: Designed, analyzed and interpreted the data; Contributed reagents, materials, analysis tools or data; Wrote the paper.

Collins Onyenaka; Tolu Adebusuyi: Analyzed and interpreted the data; Wrote the paper.

\section{Funding statement}

This work was supported by research infrastructure support from National Institute of Minority Health and Health Disparities/National Institutes of Health, Bethesda, Maryland, USA. (grant number 5G12MD007605-26).

\section{Data availability statement}

Data associated with this study has been deposited at bioRxiv under the accession number https://doi.org/10.1101/2020.08.14.250480.

Declaration of interests statement

The authors declare no conflict of interest.

\section{Additional information}

No additional information is available for this paper.

\section{References}

Adlard, P.A., Cherny, R.A., Finkelstein, D.I., Gautier, E., Robb, E., Cortes, M., Volitakis, I., Liu, X., Smith, J.P., Perez, K., Laughton, K., Li, Q.X., Charman, S.A., Nicolazzo, J.A., Wilkins, S., Deleva, K., Lynch, T., Kok, G., Ritchie, C.W., Tanzi, R.E., Cappai, R., Masters, C.L., Barnham, K.J., Bush, A.I., 2008. Rapid restoration of cognition in alzheimer's transgenic mice with 8-hydroxy quinoline analogs is associated with decreased interstitial aß. Neuron 59.

Andersson, D.A., Gentry, C., Moss, S., Bevan, S., 2009. Clioquinol and pyrithione activate TRPA1 by increasing intracellular Zn2 + . In: Proceedings of the National Academy of Sciences of the United States of America, 106.

Auld, D.S., Kawaguchi, H., Livingston, D.M., Vallee, B.L., 1974. RNA dependent DNA polymerase (reverse transcriptase) from avian myeloblastosis virus: a zinc metalloenzyme. Proc. Natl. Acad. Sci. U. S. A 71, 2091-2095.

Ayton, S., Lei, P., Bush, A.I., 2015. Biometals and their therapeutic implications in alzheimer's disease. Neurotherapeutics.

Bednarz-Prashad, A.J., John, E.I., 1983. Effect of clioquinol, an 8-hydroxyquinoline derivative, on rotavirus infection in mice. J. Infect. Dis. 148.

Belouzard, S., Chu, V.C., Whittaker, G.R., 2009. Activation of the SARS coronavirus spike protein via sequential proteolytic cleavage at two distinct sites. In: Proceedings of the National Academy of Sciences of the United States of America.

Bohlmann, L., de Oliveira, D.M.P., El-Deeb, I.M., Brazel, E.B., Harbison-Price, N., Ong, C.L.Y., Rivera-Hernandez, T., Ferguson, S.A., Cork, A.J., Phan, M.D., Soderholm, A.T., Davies, M.R., Nimmo, G.R., Dougan, G., Schembri, M.A., Cook, G.M., McEwan, A.G., von Itzstein, M., McDevitt, C.A., Walker, M.J., 2018. Chemical synergy between ionophore PBT2 and zinc reverses antibiotic resistance. mBio 9.

BPS Bioscience. ACE2 Inhibitor Screening Assay Kit. https://bpsbioscience.com/pub/ media/wysiwyg/Proteases/79923_1.pdf.

Cahoon, L., 2009. The curious case of clioquinol. Nat. Med. 15.

Capel, R.A., Herring, N., Kalla, M., Yavari, A., Mirams, G.R., Douglas, G., Bub, G., Channon, K., Paterson, D.J., Terrar, D.A., Burton, R.A.B., 2015. Hydroxychloroquine reduces heart rate by modulating the hyperpolarization activated current If: novel electrophysiological insights and therapeutic potential. Heart Rhythm 12, 2186-2194.

Chaudhry, R., Dranitsaris, G., Mubashir, T., Bartoszko, J., Riazi, S., 2020. A country level analysis measuring the impact of government actions, country preparedness and socioeconomic factors on COVID-19 mortality and related health outcomes. EClinicalMedicine 100464, 0. 
Cherny, R.A., Ayton, S., Finkelstein, D.I., Bush, A.I., McColl, G., Massa, S.M., 2012. PBT2 reduces toxicity in a C. elegans model of polyQ aggregation and extends lifespan, reduces striatal atrophy and improves motor performance in the R6/2 mouse model of Huntington's disease. J. Huntingt. Dis. 1.

Choi, Y., Bowman, J.W., Jung, J.U., 2018. Autophagy during viral infection - a doubleedged sword. Nat. Rev. Microbiol.

Colvin, R.A., Bush, A.I., Volitakis, I., Fontaine, C.P., Thomas, D., Kikuchi, K., Holmes, W.R., 2008. Insights into Zn2+ homeostasis in neurons from experimental and modeling studies. Am. J. Physiol. Cell Physiol. 294.

Coronavirus resource center. COVID-19 dashboard by the center for systems science and engineering (CSSE) at Johns Hopkins university (JHU) [WWW Document]. URL. https://coronavirus.jhu.edu/map.html.

Cox, E.H., McLendon, G.L., 2000. Zinc-dependent protein folding. Curr. Opin. Chem. Biol,

Darby, C.M., Nathan, C.F., 2010. Killing of non-replicating Mycobacterium tuberculosis by 8-hydroxyquinoline. J. Antimicrob. Chemother. 65.

Ding, W.Q., Lin, B., Vaught, J.L., Yamauchi, H., Lind, S.E., 2005. Anticancer activity of the antibiotic clioquinol. Canc. Res.

Ding, W.Q., Yu, H.J., Lind, S.E., 2008. Zinc-binding compounds induce cancer cell death via distinct modes of action. Canc. Lett. 271.

Food and Drug Administration (FDA), 2020. Coronavirus (COVID-19) Update: FDA Issues Emergency Use Authorization for Potential COVID-19 Treatment [WWW Document]. URL. https://www.fda.gov/news-events/press-announcements/coronavirus-covid19-update-fda-issues-emergency-use-authorization-potential-covid-19-treatment. (Accessed 30 April 2020).

Giglione, C., Vallon, O., Meinnel, T., 2003. Control of protein lifespan by N-terminal methionine excision. EMBO J. 22.

Guan, W., Ni, Z., Hu, Y., Liang, W., Ou, C., He, J., Liu, L., Shan, H., Lei, C., Hui, D.S.C. Du, B., Li, L., Zeng, G., Yuen, K.Y., Chen, R., Tang, C., Wang, T., Chen, P., Xiang, J., Li, S., Wang, J.L., Liang, Z., Peng, Y., Wei, L., Liu, Y., Hu, Y.H., Peng, P., Wang, J.M., Liu, J., Chen, Z., Li, G., Zheng, Z., Qiu, S., Luo, J., Ye, C., Zhu, S., Zhong, N., 2020. Clinical characteristics of coronavirus disease 2019 in China. N. Engl. J. Med. 382.

Gui, M., Song, W., Zhou, H., Xu, J., Chen, S., Xiang, Y., Wang, X., 2017. Cryo-electron microscopy structures of the SARS-CoV spike glycoprotein reveal a prerequisite conformational state for receptor binding. Cell Res. 27.

Haase, H., Overbeck, S., Rink, L., 2008. Zinc supplementation for the treatment or prevention of disease: current status and future perspectives. Exp. Gerontol.

Hamming, I., Timens, W., Bulthuis, M.L.C., Lely, A.T., Navis, G.J., van Goor, H., 2004. Tissue distribution of ACE2 protein, the functional receptor for SARS coronavirus. A first step in understanding SARS pathogenesis. J. Pathol.

Harmer, D., Gilbert, M., Borman, R., Clark, K.L., 2002. Quantitative mRNA expression profiling of ACE 2, a novel homologue of angiotensin converting enzyme. FEBS (Fed. Eur. Biochem. Soc.) Lett.

Hoffmann, M., Kleine-Weber, H., Schroeder, S., Krüger, N., Herrler, T., Erichsen, S., Schiergens, T.S., Herrler, G., Wu, N.H., Nitsche, A., Müller, M.A., Drosten, C., Pöhlmann, S., 2020. SARS-CoV-2 cell entry Depends on ACE2 and TMPRSS2 and is blocked by a clinically proven protease inhibitor. Cell 181 .

Horby, P., Lim, W.S., Emberson, J., Mafham, M., Bell, J., Linsell, L., Staplin, N., Brightling, C., Ustianowski, A., Elmahi, E., 2020. Effect of Dexamethasone in Hospitalized Patients with COVID-19: Preliminary Report.

Huang, C., Wang, Y., Li, X., Ren, L., Zhao, J., Hu, Y., Zhang, L., Fan, G., Xu, J., Gu, X., Cheng, Z., Yu, T., Xia, J., Wei, Y., Wu, W., Xie, X., Yin, W., Li, H., Liu, M., Xiao, Y., Gao, H., Guo, L., Xie, J., Wang, G., Jiang, R., Gao, Z., Jin, Q., Wang, J., Cao, B., 2020 Clinical features of patients infected with 2019 novel coronavirus in Wuhan, China. Lancet 395.

Imai, Y., Kuba, K., Rao, S., Huan, Y., Guo, F., Guan, B., Yang, P., Sarao, R., Wada, T., Leong-Poi, H., Crackower, M.A., Fukamizu, A., Hui, C.C., Hein, L., Uhlig, S., Slutsky, A.S., Jiang, C., Penninger, J.M., 2005. Angiotensin-converting enzyme 2 protects from severe acute lung failure. Nature 436, 112-116.

Kam, Y.W., Okumura, Y., Kido, H., Ng, L.F.P., Bruzzone, R., Altmeyer, R., 2009. Cleavage of the SARS coronavirus spike glycoprotein by airway proteases enhances virus entry into human bronchial epithelial cells in vitro. Plos One 4.

Kirchdoerfer, R.N., Cottrell, C.A., Wang, N., Pallesen, J., Yassine, H.M., Turner, H.L., Corbett, K.S., Graham, B.S., McLellan, J.S., Ward, A.B., 2016. Pre-fusion structure of a human coronavirus spike protein. Nature 531.

Kono, R., 1971. Subacute myelo-optico-neuropathy, a new neurological disease prevailing in Japan. Jpn. J. Med. Sci. Biol. 24.

Kuba, K., Imai, Y., Rao, S., Gao, H., Guo, F., Guan, B., Huan, Y., Yang, P., Zhang, Y., Deng, W., Bao, L., Zhang, B., Liu, G., Wang, Z., Chappell, M., Liu, Y., Zheng, D., Leibbrandt, A., Wada, T., Slutsky, A.S., Liu, D., Qin, C., Jiang, C., Penninger, J.M., 2005. A crucial role of angiotensin converting enzyme 2 (ACE2) in SARS coronavirusinduced lung injury. Nat. Med.

Lannfelt, L., Blennow, K., Zetterberg, H., Batsman, S., Ames, D., Harrison, J., Masters, C.L. Targum, S., Bush, A.I., Murdoch, R., Wilson, J., 2008. Safety, efficacy, and biomarker findings of PBT2 in targeting Abeta as a modifying therapy for Alzheimer's disease: a phase IIa, double-blind, randomised, placebo-controlled trial. Lancet Neurol.

Li, F., 2015. Receptor recognition mechanisms of coronaviruses: a decade of structural studies. J. Virol. 89.

Li, W., Zhang, C., Sui, J., Kuhn, J.H., Moore, M.J., Luo, S., Wong, S.K., Huang, I.C., Xu, K., Vasilieva, N., Murakami, A., He, Y., Marasco, W.A., Guan, Y., Choe, H., Farzan, M., 2005. Receptor and viral determinants of SARS-coronavirus adaptation to human ACE2. EMBO J. 24.

Li, F., Li, W., Farzan, M., Harrison, S.C., 2005. Structural biology: structure of SARS coronavirus spike receptor-binding domain complexed with receptor. Science.

Lind, S.E., Park, J.S., Drexler, J.W., 2009. Pyrithione and 8-hydroxyquinolines transport lead across erythrocyte membranes. Transl. Res. 154.
Lowther, W.T., Matthews, B.W., 2000. Structure and function of the methionine aminopeptidases. Biochim. Biophys. Acta Protein Struct. Mol. Enzymol.

Maddox, C.B., Rasmussen, L., White, E.L., 2008. Adapting cell-based assays to the highthroughput screening platform: problems encountered and lessons learned. J. Lab. Autom. 13.

Madjid, M., Safavi-Naeini, P., Solomon, S.D., Vardeny, O., 2020. Potential effects of coronaviruses on the cardiovascular system: a review. JAMA Cardiol.

Madu, I.G., Roth, S.L., Belouzard, S., Whittaker, G.R., 2009. Characterization of a highly conserved domain within the severe acute respiratory syndrome coronavirus spike protein S2 domain with characteristics of a viral fusion peptide. J. Virol. 83.

Mao, X., Schimmer, A.D., 2008. The toxicology of Clioquinol. Toxicol. Lett.

Mao, L., Wang, M., Chen, S., He, Q., Chang, J., Hong, C., Zhou, Y., Wang, D., Miao, X., Hu, Y., Li, Y., Jin, H., Hu, B., 2020. Neurological manifestations of hospitalized patients with COVID-19 in wuhan, China: a retrospective case series study. SSRN Electron. J.

Mathewson, A.C., Bishop, A., Yao, Y., Kemp, F., Ren, J., Chen, H., Xu, X., Berkhout, B., van der Hoek, L., Jones, I.M., 2008. Interaction of severe acute respiratory syndromecoronavirus and NL63 coronavirus spike proteins with angiotensin converting enzyme-2. J. Gen. Virol. 89.

McInerney, M.P., Volitakis, I., Bush, A.I., Banks, W.A., Short, J.L., Nicolazzo, J.A., 2018. Ionophore and biometal modulation of P-glycoprotein expression and function in human brain microvascular endothelial cells. Pharmaceut. Res. 35.

Meade, T.W., 1975. Subacute myelo optic neuropathy and clioquinol. An epidemiological case history for diagnosis. Br. J. Prev. Soc. Med.

Millet, J.K., Whittaker, G.R., 2015. Host cell proteases: critical determinants of coronavirus tropism and pathogenesis. Virus Res. 202.

Nami, B., Ghanaeian, A., Ghanaeian, K., Nami, N., 2020. The Effect of ACE2 Inhibitor MLN-4760 on the Interaction of SARS-CoV-2 Spike Protein with Human ACE2: A Molecular Dynamics Study.

National institute of Health (NIH), 2020. Potential Antiviral Drugs under Evaluation for the Treatment of COVID-19 [WWW Document]. URL. https://www.covid19treatmen tguidelines.nih.gov/antiviral-therapy/. (Accessed 23 July 2020).

Nishiga, M., Wang, D.W., Han, Y., Lewis, D.B., Wu, J.C., 2020. COVID-19 and cardiovascular disease: from basic mechanisms to clinical perspectives. Nat. Rev. Cardiol.

Olaleye, O., Raghunand, T.R., Bhat, S., Chong, C., Gu, P., Zhou, J., Zhang, Y., Bishai, W.R., Liu, J.O., 2011. Characterization of clioquinol and analogues as novel inhibitors of methionine aminopeptidases from Mycobacterium tuberculosis. Tuberculosis 91.

Perez, D.R., Sklar, L.A., Chigaev, A., 2019. Clioquinol: to harm or heal. Pharmacol. Ther.

Plasencia-Garcia, B.O., Rodriguez-Menendez, G., Rico-Rangel, M.I., Rubio-Garcia, A., Torello-Iserte, J., Crespo-Facorro, B., 2020. Drug-Drug interactions between COVID19 treatments and antipsychotics drugs: integrated evidence from 4 databases and a systematic review. medRxiv, 2020.06.04.20122416.

RayBiotech, 2020. COVID-19 Spike-ACE2 Binding Assay Kit [WWW Document]. URL. htt ps://doc.raybiotech.com/pdf/Manual/CoV-SACE2_2020.07.09.pdf.

Ritchie, C.W., Bush, A.I., Mackinnon, A., Macfarlane, S., Mastwyk, M., MacGregor, L., Kiers, L., Cherny, R., Li, Q.X., Tammer, A., Carrington, D., Mavros, C., Volitakis, I., Xilinas, M., Ames, D., Davis, S., Beyreuther, K., Tanzi, R.E., Masters, C.L., 2003. Metal-protein attenuation with iodochlorhydroxyquin (clioquinol) targeting a $\beta$ amyloid deposition and toxicity in alzheimer disease: a pilot phase 2 clinical trial. Arch. Neurol. 60.

Roden, D.M., Harrington, R.A., Poppas, A., Russo, A.M., 2020. Considerations for drug interactions on QTc interval in exploratory COVID-19 treatment. J. Am. Coll. Cardiol. 75, 2623 LP - 2624.

Sanders, J.M., Monogue, M.L., Jodlowski, T.Z., Cutrell, J.B., 2020. Pharmacologic treatments for coronavirus disease 2019 (COVID-19): a review. J. Am. Med. Assoc,.

Schimmer, A.D., Jitkova, Y., Gronda, M., Wang, Z., Brandwein, J., Chen, C., Gupta, V., Schuh, A., Yee, K., Chen, J., Ackloo, S., Booth, T., Keays, S., Minden, M.D., 2012. A phase i study of the metal ionophore clioquinol in patients with advanced hematologic malignancies. Clin. Lymphoma, Myeloma \& Leukemia 12.

Severson, W.E., Shindo, N., Sosa, M., Fletcher, T., White, E.L., Ananthan, S., Jonsson, C.B., 2007. Development and validation of a high-throughput screen for inhibitors of SARS $\mathrm{CoV}$ and its application in screening of a 100,000-compound library. J. Biomol. Screen 12.

Shi, L., Huang, C., Luo, Q., Xia, Y., Liu, W., Zeng, W., Cheng, A., Shi, R., Zhengli, C., 2020. Clioquinol improves motor and non-motor deficits in MPTP-induced monkey model of Parkinson's disease through AKT/mTOR pathway. Aging 12.

Slomski, A., 2020. No benefit for lopinavir-ritonavir in severe COVID-19. J. Am. Med. Assoc.

Song, W., Gui, M., Wang, X., Xiang, Y., 2018. Cryo-EM structure of the SARS coronavirus spike glycoprotein in complex with its host cell receptor ACE2. PLoS Pathog.

South, A.M., Diz, D.I., Chappell, M.C., 2020. COVID-19, ACE2, and the cardiovascular consequences. Am. J. Physiol. Heart Circ. Physiol. 318.

Tavares, G. de S.V., Mendonça, D.V.C., Lage, D.P., Granato, J. da T., Ottoni, F.M., Ludolf, F., Chávez-Fumagalli, M.A., Duarte, M.C., Tavares, C.A.P., Alves, R.J., Coimbra, E.S., Coelho, E.A.F., 2018. Antileishmanial activity, cytotoxicity and mechanism of action of clioquinol against leishmania infantum and leishmania amazonensis species. Basic Clin. Pharmacol. Toxicol. 123.

Tavares, G.S.V., Mendonça, D.V.C., Pereira, I.A.G., Oliveira-Da-Silva, J.A., Ramos, F.F., Lage, D.P., MacHado, A.S., Carvalho, L.M., Reis, T.A.R., Perin, L., Carvalho, A.M.R.S., Ottoni, F.M., Ludolf, F., Freitas, C.S., Bandeira, R.S., Silva, A.M., ChávezFumagalli, M.A., Duarte, M.C., Menezes-Souza, D., Alves, R.J., Roatt, B.M., Coelho, E.A.F., 2020. A clioquinol-containing Pluronic ${ }^{\circledR F} 127$ polymeric micelle system is effective in the treatment of visceral leishmaniasis in a murine model. Parasite 27. 
Towler, P., Staker, B., Prasad, S.G., Menon, S., Tang, J., Parsons, T., Ryan, D., Fisher, M., Williams, D., Dales, N.A., Patane, M.A., Pantoliano, M.W., 2004. ACE2 X-ray structures reveal a large hinge-bending motion important for inhibitor binding and catalysis. J. Biol. Chem. 279, 17996-18007.

Verma, H.K., Merchant, N., Verma, M.K., Kuru, C.I., Singh, A.N., Ulucan, F., Verma, P., Bhattacharya, A., Bhaskar, L.V.K.S., 2020. Current updates on the European and WHO registered clinical trials of coronavirus disease 2019 (COVID-19). Biomed. J.

Vickers, C., Hales, P., Kaushik, V., Dick, L., Gavin, J., Tang, J., Godbout, K., Parsons, T., Baronas, E., Hsieh, F., Acton, S., Patane, M., Nichols, A., Tummino, P., 2002. Hydrolysis of biological peptides by human angiotensin-converting enzyme-related carboxypeptidase. J. Biol. Chem. 277.

Walls, A.C., Park, Y.J., Tortorici, M.A., Wall, A., McGuire, A.T., Veesler, D., 2020. Structure, function, and antigenicity of the SARS-CoV-2 spike glycoprotein. Cell 181.

Wang, Qihui, Zhang, Y., Wu, L., Niu, S., Song, C., Zhang, Z., Lu, G., Qiao, C., Hu, Y., Yuen, K.Y., Wang, Qisheng, Zhou, H., Yan, J., Qi, J., 2020. Structural and functional basis of SARS-CoV-2 entry by using human ACE2. Cell 181.

Warner, F.J., Guy, J.L., Lambert, D.W., Hooper, N.M., Turner, A.J., 2003. Angiotensin converting enzyme-2 (ACE2) and its possible roles in hypertension, diabetes and cardiac function. Lett. Pept. Sci.

World Health Organization, 2020a. Director-General's Opening Remarks at the media Briefing on COVID-19 [WWW Document]. URL. https://www.who.int/dg/speech es/detail/who-director-general-s-opening-remarks-at-the-media-briefing-on-covid19-11-march-2020. (Accessed 10 March 2020).

World Health Organization, 2020b. Coronavirus Disease 2019 (COVID-19) Situation Report - 46- 6 March 2020. [WWW Document]. URL. https://www.who.int/docs/ default-source/coronaviruse/situation-reports/20200306-sitrep-46-covid-19.pdf?sf vrsn=96b04adf_4. (Accessed 5 March 2020).

Wrapp, D., Wang, N., Corbett, K.S., Goldsmith, J.A., Hsieh, C.L., Abiona, O., Graham, B.S., McLellan, J.S., 2020. Cryo-EM structure of the 2019-nCoV spike in the prefusion conformation. Science.

Yan, R., Zhang, Y., Li, Y., Xia, L., Guo, Y., Zhou, Q., 2020. Structural basis for the recognition of SARS-CoV-2 by full-length human ACE2. Science.

You, Z., Ran, X., Dai, Y., Ran, Y., 2018. Clioquinol, an alternative antimicrobial agent against common pathogenic microbe. J. Mycol. Med. 28.

Yu, H., Zhou, Y., Lind, S.E., Ding, W.Q., 2009. Clioquinol targets zinc to lysosomes in human cancer cells. Biochem. J. 417.

Zhang, M., Xie, M., Li, S., Gao, Y., Xue, S., Huang, H., Chen, K., Liu, F., Chen, L., 2017. Electrophysiologic studies on the risks and potential mechanism underlying the proarrhythmic nature of azithromycin. Cardiovasc. Toxicol. 17, 434-440.

Zhu, N., Zhang, D., Wang, W., Li, X., Yang, B., Song, J., Zhao, X., Huang, B., Shi, W. Lu, R., Niu, P., Zhan, F., Ma, X., Wang, D., Xu, W., Wu, G., Gao, G.F., Tan, W., 2020. A novel coronavirus from patients with pneumonia in China, 2019. N. Engl. J. Med. 382. 